\title{
Review of Environmental and Human Exposure to Persistent Organic Pollutants
}

\author{
Jolly Jacob ${ }^{1} \&$ Jacob Cherian ${ }^{2}$ \\ ${ }^{1}$ Department of Applied Sciences, College of Arts and Sciences, Abu Dhabi University Abu Dhabi, UAE \\ ${ }^{2}$ Department of Management, College of Business Administration, Abu Dhabi University, Abu Dhabi, UAE \\ Correspondence: Jolly Jacob, Department of Applied Sciences, College of Arts and Sciences, Abu Dhabi \\ University Abu Dhabi, UAE. E-mail: jollyjacob70@hotmail.com
}

Received: May 21, 2013 Accepted: June 24, 2013 Online Published: August 30, 2013

doi:10.5539/ass.v9n11p107 URL: http://dx.doi.org/10.5539/ass.v9n11p107

\begin{abstract}
Persistent Organic Pollutants (POPs) have a very long life and they persist in the environment for a very long time and have a long life in soils, sediments, air or biota. There has been a recent upsurge of interest in the development of low cost reliable measures which are required in order to detect and trace current concentration levels of persistent organic pollutants (POPs) as a result of increasing levels of accumulation within the living organism, transformation as well as toxicity making it ideal to examine the impact on the environment which has been the focus of this review. There are still debates that rage around the issue including relevance of some physio pathologic effects of POPs on the human body along with epidemiological and clinical effects on the human population. Hence in this review there is examination, debating and presenting of arguments in relation to the sources, properties and types of POPs in the atmosphere along with examining the toxicity, analytical techniques and monitoring of atmospheric and biological concentration of POPs in the human population.
\end{abstract}

Keywords: persistent organic pollutants, sources, properties, atmospheric and biological concentration of POP, toxicity

\section{Introduction}

Persistent Organic Pollutants (POP) are a class of chemical compounds that are derived from a particular series or families of chemicals (El-Shahawi, et al., 2010) which are highly chlorinated and possess a molecular weight from 200 to $500 \mathrm{Da}$. Their vapour pressure is found to be lower than $1000 \mathrm{~Pa}$ (Ross et al., 2009). POPs have a very long life and they persist in the environment for a long time including soils, as sediments in air or biota (Kallenborn, 2006; Porta et al., 2008). There is no consensus among the academic professionals (Xie et al., 2010; Wang et al., 2012) on the exact meaning of the term persistent and how long a product should exist in the environment to be labelled as persistent compound. However, in practice, POPs are classified as compounds which can have half-life period running into many years (Xie et al., 2010).

Toxicity, high persistence and bioaccumulation ability are the factors that are the primary focus in the latest environment based studies. According to Lerche et al., (2002), POPs are among the most important subset of Persistent, Bioaccumulative and Toxic (PBT) chemicals including pesticides like $\gamma$-hexachlorocyclohexane or 1,1,1-trichloro-2,2-diethane, polychlorinated biphenyls, polycyclic aromatic hydrocarbons (PAHs), polychlorinated naphthalenes, polychlorinated dibenzo-p-dioxins, polychlorinated dibenzofurans, as well as groups of brominated flame retardants (BFRs) such as polybrominated biphenyls, hexabromocyclododecane, chlorine-containing molecules like polybrominated diphenyl ethers and tetrabromobisphenol. The overall quantity of POPs in the environment increases due to the addition of PAH and BFR materials as a result of massive domestic waste disposal, pollution from chemical plants, combustion of fossil fuels, the wide-spread use of pesticides and pollution from chemical plants (Muir \& Howard, 2006).

Humans are known to store POPs in their fat tissues. Animal fat tissues as well typically store polychlorinated biphenyls (PCBs), trans-nonachlor, dioxins, hexachlorobenzene, dichlorodiphenyldichloroethan and the hexachlorociclohexanes (Porta \& Zumeta, 2002; Liem et al., 2000; Sanz-Gallardo et al., 1999; DeVoto et al., 1998; Porta et al., 2003). However, it has been discovered that humans who eat meat also ingest some of the POPs that occur within the fatty tissues of the animals (Schafer \& Kegley, 2002; van Larebeke et al., 2001; 
Kalantzi et al., 2001; Schepens et al., 2001). Despite banning of most dangerous POPs, there are others such as DDT which is still used widely and is even today being exposed to humans through food chains.

The most important challenge to the human society is to reduce the amount of POPs contamination and use in food chain (Porta, 2002). In order to keep a regular check on the quantity of POPs in the food chains, there is a necessity to monitor regularly along with the policies and processes initiated to reduce the amounts of POPs in the food chains. The policies to reduce POPs include 'The Stockholm Treaty' on POPs (Porta \& Zumeta, 2002) which was instituted to monitor the concentration levels of POPs in the general population (United Nations Environment Programme, 2007). There are still debates on the issue of the social relevance of some physiopathological effects of POPs on the human body along with epidemiological and clinical effects on the human population (Weinhold, 2003; Kaiser, 2000; Lee et al., 2007; Stokstad, 2004; Myers, 2002) making it vital to examine, debate and present arguments in relation to the sources, properties and types of POPs in the atmosphere. The present review presents the toxicity and analytical techniques to monitor the atmospheric POPs in order to quantify the concentrations of POPs in the human population.

\section{Sources of POP}

POPs like dibenzofurans and dioxins are released in the atmosphere by natural sources like volcanic activities or due to forest fires. POPs as their name suggests, are quite durable and are not prone to degradation quickly in the environment. Some of the major man made sources of POPs are from the industrial sources like incinerating plants, power stations, use of agricultural sprays, heating stations and evaporation from water surfaces, soil, or from the landfills. The above mentioned sources are deliberate man made sources, however there are also other man made sources from which POPs are released but are unintentional. These sources are bushfires and putrefaction, chemical facilities, wastes containing PCBs (this includes waste that stems from the use of obsolete oil or cooked oil, cement manufacture, lixiviation of dumps, the repairing and maintenance of equipments, sewage sludge, incineration-municipal, hazardous, medical waste, landfills-hazardous waste/plastic waste, demolition of building, industry-chlor-alkali plants, evaporation, organ chlorine pesticide plant and cock plant, cement manufacture, organochlorine pesticide storage, animal carcass incinerator, fly ash storage and combustion of fossil fuels) and diverse combustions (Ying et al., 2005; Wenzel et al., 2006).

Effluents from production plants as well as runoffs from fields contaminate the atmosphere. Roads and atmosphere are found to contaminate the water system with fats and oils, liquid fuels, mud, residues and deposits. Oceans and seas are identified to be the major reservoirs receiving the pollutants through numerous rivers and streams that have soaked up the atmospheric POPs and sediments, disposal systems etc and carry them to the larger water bodies. These POPs can be stored as sediments on the bottom of these water bodies and is released in natural calamities like volcanic eruptions (Galiulin et al., 2002; Petrlik et al., 2001).

\section{Properties of POPs}

The chemical and physical properties as well as the type of environment influence the chemical behaviour in a particular environment. The molecules' structure and the nature of the atoms constituting the molecules determine both their chemical and physical properties. The physico-chemical properties that allow the compounds to exist either in the vapour phase or be adsorbed by atmospheric particles are: very low and high lipid solubility as they decide their bioaccumulation in tissues, high toxicity, and semi-volatility which helps them to travel long distances in the atmosphere before being deposited (Berg et al., 1998; Guzella et al., 2005).

POPs can transmit to the ground surface by either dry deposition such as ashes, water sediments or by wet deposition such as vapour or gaseous phase substance by rain and their subsequent deposition. Majority of POPs exhibit only minimal solubility in water. At the same time, it can be easily absorbed on dry deposits such as soil, ash, water sediments, and dust particles. Moreover, they can also exhibit reasonable solubility in organic fluids such as liquid fuels, fats and oils. This indicates higher the concentration of solid particles and polluting organic fluids in water, the greater the POP content (Katsoyiannis \& Samara, 2005).

The general characteristics of POPs are that they belong to a class of organic compounds that are hydrophobic and lipophilic (Vallack et al., 1998). When present in aquatic systems and soils they have a tendency to stick to the solids, especially the organic particulates, rather than the water. In organic cells, they once again have a tendency to segregate into lipids which are then stored inside the fatty tissues of the organisms, rather than entering the aqueous milieu of cells (Wang et al., 2010). A major reason why the POPs tend to accumulate in the food chain as metabolism is a slow process and tends to accumulate in organisms (Muir \& Howard 2006).

In the atmosphere, POPs go through slow decomposition in the presence of solar radiation (photolysis), humidity and other organic and inorganic substances. The heat and other atmospheric conditions of geographical region 
determine the persistence of POPs in the atmosphere. While in the tropical regions, many POPs last for only several days, they can last for several years in the polar atmosphere (Huang et al., 2006). The consequence of their atmospheric stability is their transport through hundreds and thousands of kilometres. Evidently, traces of pesticides, which are still predominantly used in Africa and South America, have been found in the North Pole region. Confirmation of their air-borne transport was done by measuring their presence in ice and snow in the North Pole and also in the organisms present in the North Sea. Since these compounds have never been utilized in the North Pole, their presence proves that the only way they may have be incorporated is through long distance transport (Kumar et al., 2005; Berg et al., 1998).

Bioaccumulation leads to biomagnification of some persistent organic substances; hence, these molecules are found to occur at higher concentrations in animals that occupy the highest levels in the food chain. This happens because the predators prey on animals that are hundreds of times their own weight (Harrad, 2009).

In Table 1, the most important physico-chemical properties of the 12 POPs that are of toxicological interest to the scientists have been listed. The table includes organochloride insecticides, such as DDT, dieldrin, chlordane, and toxaphene. Many industrial products or by-products are found to consist of polychlorinated dibenzo- $p$-dioxins and polychlorinated dibenzofurans.

Persistent organic pollutants also tend to turn into a gaseous state under environmental temperatures (UNIDO, 2000). Thus they may volatilise from sources like water bodies, soil or the vegetation into the atmosphere and can travel long distances before they get absorbed or deposited elsewhere (Fiedler, 2003). This entire cycle of volatilisation and re-deposition can occur a number of times. Thus, these organic compounds can originate in one place and can get accumulated at a completely different place. Based on the atmospheric temperature and the physico-chemical characteristics of the chemicals, POPs may exist in between particles and aerosols in the atmosphere (Kumar et al., 2005).

Table 1. Physio chemical properties of certain POPs

\begin{tabular}{llllll}
\hline S No & Name of compound & Molecular weight & Water Solubility & log Kow & Vapour Pressure \\
\hline 1 & Aldrin & 365 & $27 \mu \mathrm{gl}-1$ & $5.17-7.4$ & 2.3 X 10-5 \\
2 & Chordane & 410 & $56 \mu \mathrm{gl}-1$ & $4.58-5.57$ & $0.98 \times 10-5$ \\
3 & DDT & 355 & $1.2-5.5 \mu \mathrm{gl}-1$ & 6.19 & $0.2 \times 10-6$ \\
4 & Dielctrin & 381 & $140 \mu \mathrm{gl}-1$ & $3.69-6.2$ & $1.78 \times 10-7$ \\
5 & PCCDs & $322-460$ & $0.074-19.3 \mathrm{ngl}-1$ & $6.80-8.20$ & $8.25 \times 10-13$ \\
6 & PCDFs & $306-444$ & $1.16-419$ ngl-1 & $6.53-8.7$ & 3.75 X 10-13 \\
\hline
\end{tabular}

\section{Types of POPs}

\subsection{Pesticides}

In many countries, a slow but steady move towards the use of less bioaccumulative or less persistent pesticides has been noticed. However, in countries that are developing, which include the tropical countries, organochlorine pesticides (eg., $\mathrm{HCH}, \mathrm{DDT}$, heptachlor, and chlordane) are still being employed by the farmers in agriculture and in the control of arthropods of veterinary or medical importance. As a consequence of this, the levels of $\mathrm{HCH}$ and DDT are found to decline in human tissues in developed countries, while levels of POP in human tissues are stable in most of the developing countries (Loganathan \& Kannan, 1994).

National and international organizations are still advocating the use of many of the organochloro pesticides, in particular DDT, for the control of lice, mosquitoes, and flies that play a role in the spread of malaria, typhoid and typhus. However, according to the WHO, with the decreasing world-wide production, of DDT, the speedy development of insect resistance and the potential emergence of other alternatives, the use of DDT may stop without the legal system intervening. While chlordane and heptachlor are being utilized in the control of termites, their use is being controlled steadily in many countries.

Pesticides not bound to soil or not accumulated in animals and plants, but it drains into rivers and lakes and thereby affecting the aquatic food chain systems. Pesticides with high chlorinated levels have been identified in Indonesia, Malaysia, China, Thailand, Tanzania and Colombia rivers at levels indicating high potential hazards (Repetto \& Baliga, 1996). These pesticides are semi-volatile and hence can be dispersed by air also. It has been 
noted that the semi-volatile compound that are persistent such as DDTs and HCHs, released in the tropical regions are inclined to be redistributed globally (Iwata et al., 1994). Considering redistribution of chlorinated pesticides, a study by Simonich and Hites (1995) indicates that high chlorinated pesticides are not only used by developing countries but also used by industrialized countries like southern Ontario, southern USA, the Caribbean and Mexico, even though the compounds have been banned for many years (Hoff et al., 1992). Examples of such compounds are dieldrin, HCHs, DDT, chlordane, and toxaphene.

According to Iwata et al. (1993), the main source for the latitudinal distribution of HCHs and DDTs has found to be transmitted from mid to low latitudes in 1980s. In 1996, Weber and Goerke (1996) discovered that the levels of p,p'-DDE (a metabolite of DDT) have shown an increase in many Antarctic fish between the years 1987 and 1991. This reflects that organochlorine pesticides are being used continually and that sometimes it is increasing in countries that are developing and present near the tropics.

\subsection{Industrial Chemicals}

Polychlorinated biphenyls (PCB compounds) are reported as environmental pollutants in 1996. Bird tissue, water, fish tissues and sediments have been contaminated by these PCB as it has 2-10 chlorinated compounds attached to the biphenyl molecule. A classic example of these compounds is Monochlorinated biphenyls wherein a single chlorinated atom is bound to the biphenyl molecule. Figure 1 illustrates the common chemical structure of chlorinated biphenyls. So far, the researchers have identified 209 different PCB congeners. As these compounds can resist degradation, they become persistent in the environment for a long period and a major pollutant in atmospheric as well as water and gets transported through the same medium (Korytar et al., 2002; Panic \& Gorecki, 2006; Villa et al., 2003).<smiles>[18O]c1c(Cl)c(Cl)cc2c1Oc1cc(Cl)c(Cl)cc1O2</smiles><smiles>Clc1cc2oc3cc(Cl)c(Cl)cc3c2cc1Cl</smiles>

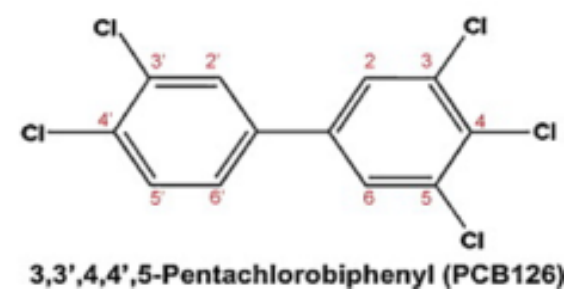

Figure 1. Basic structures of the chlorinated dibenzo-p-dioxins (dioxins), chlorinated dibenzofurans (furans) and polychlorinated biphenyls (PCBs)

Source: El-Shahawi et al., 2010.

\subsection{Polycyclic Aromatic Hydrocarbons (PAHs)}

In PAHs, two or more carbon and hydrogen containing benzene rings are fused in linear, angular or cluster formats. Stable C-C bonds form the central molecular structure of these PAHs. As the PAHs are identified to be potential carcinogens, the US Environmental Protection Agency (EPA) proclaimed 16 PAHs as major pollutants. Following this announcement, there has been more focus on reducing their distribution and adverse effects.

Soil, air and various consumable products are being contaminated with these PAHs. They are present throughout the world as they are emitted by plants after prairie fires. But, anthropogenic processes such as fossil fuel combustion and effluents from industrial processing expel PAHs and increasing its levels in the environment. 
PAHs may also be released via agricultural fires and cooking. The researchers have found out the characteristics of the precursor sources (i.e., whether they are pyrogenic or petrogenic) through the PAHs distributed in the sediments (Aboul-Kassim \& Simueit, 1995; ATSDR, 1995; Zielinska \& Samy, 2006).

\section{Evidence for Long-Range Transport of POPs}

As these POPs are volatile and resistant to biological, photolytic and chemical degradation, they become persistent throughout the world. Each continent and even remote areas like the deserts, the Arctic (Barrie et al., 1992), the Antarctic (Tanabe et al., 1982; Bidleman et al., 1993) and open oceans (Hargrave et al., 1988; Iwata et al., 1993) reported high levels of POPs. The distribution of PCBs around the world has been discussed in many studies (Mes, 1987). Researchers have reported the ubiquitous nature of these chemicals in their studies. For example, Risebrough and Carmignani (1972), George and Frear (1966) reported the contamination of the Antarctic by DDTs and PCBs. Following these studies Barrie (1986), Goldberg (1975) Bowes and Jonkel (1975), and Clausen and Berg (1975), documented the presence of several organochlorines in the Arctic. Wania and Mackay (1993) reported the high level distribution of POPs in the Polar Regions. Few researchers observed high concentration of some particular organochlorines in plankton (Bidleman et al., 1989), wild animals (Muir et al., 1988; Norstrom et al., 1988), seawater (Hargrave et al., 1988) and rainfall (Gregor \& Gummer, 1989).

In a study, HCB concentration in Antarctic fish was found to be the same level as that of North Sea fish (Weber \& Goerke, 1996). The Arctic marine ecosystems and other ecosystems (Barrie et al., 1992) that include predators and aboriginal people who consume marine mammals and fish as their staple food have been reported with high level of POPs (Kinloch et al., 1992). These ecosystems have been extremely polluted by POPs (Dewailly et al., 1989).

\section{The Global Distillation/Fractionation Effect}

The effect of global distillation/fractionation is highly responsible for the prevalence and persistence of POPs in Polar Regions (Wania \& Mackay, 1993). The pesticides that have been used in warm climatic condition may evaporate and migrate to cold regions where they can be condensed and become persistent in the environment. This 'rule of the cold wall' illustrates the organochlorines existence in circumpolar wildlife (Rappe, 1974). The mechanism of transport of DDT from continents to oceans, Goldberg (1975) coined the term 'global distillation'. This effect is also called as the 'cold trap' (Rahn \& Heidam, 1981), the 'cold condensation' (Ottar, 1981), or the 'cold finger' (Weschler, 1981). It is identified from a recent study that the chronic spatial distribution patterns of organochlorine chemicals has increased in recent years due to the physico-chemical characteristics of these substances and some particular characteristic features of cold environments (Wania \& Mackay, 1993).

Generally, the distribution pattern of a substance is determined by its volatility and atmospheric temperature. As a result, the highly volatile POPs have a tendency to migrate from hot and temperate areas to colder areas. The migration pattern of POPs to higher latitudes that consist of a sequence of short jumps is called as 'grasshopper effect' in which they stop their migration and remain suspended at mid-altitudes if there is a change in the seasonal temperature and continue to migrate when there is a favourable temperature (Wania \& Mackay, 1996) (Figure. 2). A characteristic environmental condensation temperature or temperature range is possessed by each POP. As these POPs are volatile in nature, they can easily migrate to the Polar Regions by means of air. As a result, based on the degree of volatility they have been distributed throughout the world and this kind of distribution is called 'global fractionation'. As these pollutants may expel from accumulated chemical reservoirs, they will continue to contaminate the environment even though there is a decline or pause in their release. 


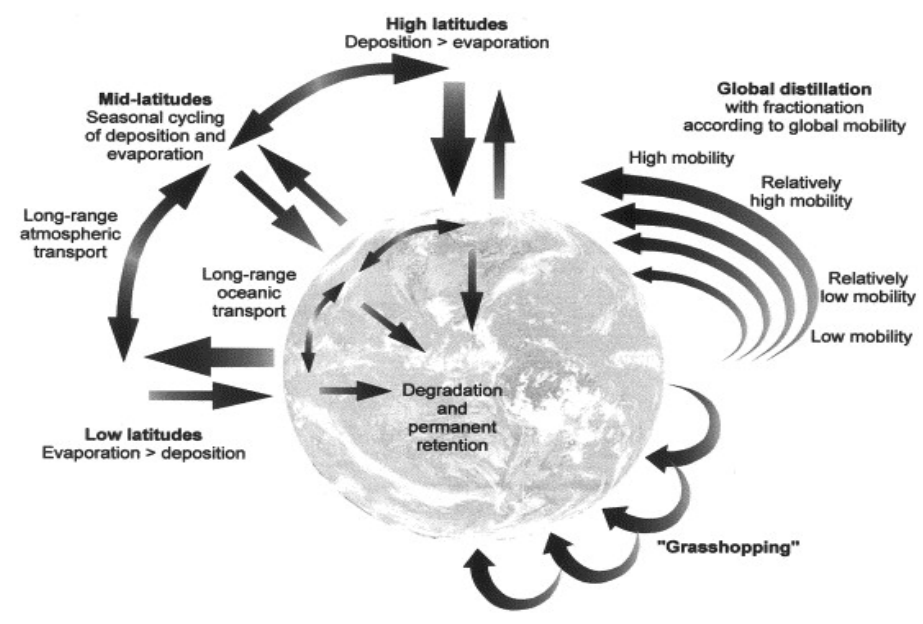

Figure 2. POP global migration processes

Source: Wania \& Mackay, 1996.

\section{Extraction of POPs}

Supercritical fluid extraction or as it is commonly known as 'SFE' is an extraction technique that makes use of a gas at the critical point wherein the high pressure and temperatures make the gas exhibit fluid like properties in order to extract analytes from the matrix. The main benefit of this process is that the gas extracted can be evaporated without any solvent disposal. SFE techniques tend to behave in a different manner in comparison to traditionally used solvent based extraction methods, where the recoveries can be increased or reduced as per demand. The Pressurized Liquid Extraction (PLE) technique of extraction, an accelerated solvent extraction process was derived from SFE technique. In SFE extractions, certain solvents were included to act as modifiers to mimic classical liquid extractions. Classical extraction recoveries were best matched only by solvent modifiers and SFE without extraction gas and this led to the development of PLE. Another technique used for extraction uses enclosed vessels in a bid to raise the pressure and subsequently enhance the efficiency of extraction and this technique is called as Microwave assisted extraction (MAE). The heat required for the extraction process is supplied by polar solvents such as water or acetone. San et al., (2005) reported the analysis of samples that were extracted using the MAE process, clearly pointed out that it took far less time to dry out the sample when compared to other processes.

Another technique that is used to improve efficiency and decrease the time involved in the analysis process is solid phase extraction. This method also reduces the amount of solvent used for the extraction of water and waste water samples, even with significant particulate loadings (San et al., 2005). By using this technique the particulates that are gathered by the C18 extraction disks are quantitatively separated without using PLE extraction or Soxhlet. According to Katsoyiannis and Samara (2007) and Taylor et al., (1995), water sampling; air sampling or even sediment sampling can be done using SPMD sampling techniques. Water sampling in the case of SPMD sampling technique can be done passively using semi permeable membrane devices.

Another study by Namiesnik et al., (2005) has delved into the passive sampling methods in environmental sampling. The study revealed that passive sampling methods are based up on the unobstructed flow of the analytes from the sampling medium to the collecting medium. The medium lowers the overall requirement for energy significantly along with the cost required for the analysis process due to reduced sampling events and analyte loss during shipping and storage as the analyte is on a trapping medium. Different extraction methods are presented in table 2 . 
Table 2. Extraction techniques of POPs in various matrices at different regions

\begin{tabular}{|c|c|c|c|}
\hline Sample Matrix & Extraction method & Analyte & References \\
\hline Sediment & $\begin{array}{l}\text { SE, LSE, LLE, } \\
\text { SFE, MASE }\end{array}$ & $\begin{array}{l}\text { PCBs, OCPs, PAHs, } \\
\text { HCB, HCH, } \\
\text { DDT, PBDEs, } \\
\text { PCDD/Fs }\end{array}$ & $\begin{array}{l}\text { Fiedler, 2003; Fernandez, , Carrera\& } \\
\text { Grimalt, 2005; Hela et al., 2006; Hjelmborg, } \\
\text { Ghisari \& Jorgensen, 2006; Covaci \& } \\
\text { Schepens,2001; Chen, Wang \& Wang, 2005; } \\
\text { Ekmekci, 2005; Namiesnik et al., 2005; } \\
\text { Mannila, Koistinen\& Vartianinen,2002 }\end{array}$ \\
\hline Soil & $\begin{array}{l}\text { SE, SPE, PLE, } \\
\text { LLE, sonication }\end{array}$ & $\begin{array}{l}\text { Singapore, Australia, } \\
\text { Europe, } \\
\text { Brazil, China }\end{array}$ & $\begin{array}{l}\text { Fernandez, Carrera,2005; Heim, et al., 2003; } \\
\text { Ying et al., 2005; Zhao et al., 2006; Guitart et } \\
\text { al., 2004; Vanbeuzekekom et al., 2003; US } \\
\text { Environmental Protection Agency ,1999 }\end{array}$ \\
\hline Water & $\begin{array}{l}\text { Sonication process, } \\
\text { SPMD, LLE, } \\
\text { filter DOC }\end{array}$ & $\begin{array}{l}\mathrm{HCH}, \mathrm{HCB}, \mathrm{PCBs}, \\
\text { PAHs, OCPs }\end{array}$ & $\begin{array}{l}\text { Sanpera et al., 2003; Poon et al., 2005; Uneo } \\
\text { et al., 2003; Wang et al., 2009; Borges et al., } \\
\text { 2009; Juhasz et al., 2003; Landaluze et al., } \\
\text { 2006; Zhao, Yang \& Wang, 2007; Matheus, } \\
\text { Bononi\& Machado, } 2000\end{array}$ \\
\hline Air & $\begin{array}{l}\text { Swipe/biofilms, } \\
\text { passive sample }\end{array}$ & $\mathrm{PCDD} / \mathrm{F}, \mathrm{HCB}$ & $\begin{array}{l}\text { Landaluze et al., 2006; Rayne et al., 2005; } \\
\text { Lucaciu et al., } 2004\end{array}$ \\
\hline
\end{tabular}

Source: El-Shahawi et al., 2010.

\section{Dosage and Toxicity of POPs}

The extreme toxicity and prevalence of POPs even in remote geographical areas make them a significant concern. In the past few years toxic ecological effects of POPs have been a primary focus for researchers. Following these studies most of the countries controlled and banned the use of these POPs. Researchers identified a lot of organic substances that pollute the aquatic environment, particularly they investigated more about the toxic effects of PCBs and (OCPs) in aquatic environment. As these organic pollutants are resistant to biological degradation, they have been found in the marine environment for years together. Besides animals and plants, these POPs are present in humans (UNIDO Workshop on Contamination of Food and Agro Products, 2000; Sweetman et al., 2005).

The hormonal disturbances caused by the POPs in humans and their ability to induce abnormal functions of endocrine as well as reproductive systems in humans and animals made POPs a public concern. These pollutants (food and water) are found to create adverse environmental effects and should be eliminated from the atmosphere. These organic pollutants could develop cancer, birth defects, learning disabilities, immunological, behavioral, neurological and reproductive discrepancies in human and other animal species (Sweetman et al., 2005). Furthermore the members of the food chain such as eagles, polar bears, killer whales and human being also accumulate these toxic chemicals through food chain. Humans ingest a significant amount of POPs, in turn which lead to adverse health effects and even slow death. Their ability to cause endocrine disruption, reproductive and immune dysfunction, neurobehavioral and disorder and cancer have been demonstrated in various studies (Pauwels et al., 2000; Katsoyiannis \& Samara, 2005).

Exposure to POPs develops reduced immunity, recurrent infections, developmental abnormalities, neurobehavioral impairment and cancer and tumor induction or promotion in infants and children. Few studies proved the ability of POPs to induce breast cancer in human being. These pollutants are prevalent in aquatic environment and the aquatic animals are highly exposed to these pollutants. Through food chain, humans consume the pollutants from these aquatic animals and accumulate them in their cells (Katsoyiannis\& Samara, 2005). When compared to adults children are found to be more susceptible to the impacts of contaminants. These contaminants, especially the persistent organic pollutants could easily damage the developing cells of the children. Few studies (Bouwman, 2003; Bolt \& Degen, 2002), demonstrated the lower intelligent quotient and inability to shut out distractions in the individuals who were exposed to POPs during their childhood.

\section{Trends in Monitoring of POP}

The international chemical policy has increasingly given more importance to persistent organic pollutants over the years. These pollutants are toxic in nature and are of anthropogenic origin that are quite often challenging to 
degrade in nature and also are capable of being transported over long distances through the air. As a result, lindane $(\gamma-\mathrm{HCH})$ was constrained to six particular uses and technical HCH was limited to use as an intermediate in chemical manufacturing by the POPs protocol which was activated in the year 2003 as part of the UNECE Convention on Long-range Transboundary Air Pollution's framework. In addition to this, the use of DDT and PCBs were also strictly limited and the use of HCB was completely restricted soon afterwards. The European Union also voted to stop the use of lindane as a protection agent and the compound was supposed to have been completely stopped and removed by the year 2002 (OSPAR, 2004). Governments all over the world are taking measures to stop or reduce the amount of usage of POPs in the environment (UNEP, 2007).

The government's actions in relation to the use of POPs have to be based on constant monitoring of the amount of POPs in the environment, food chains and in the air. Gioia et al., (2007) and Shatalov et al., (2005), are two studies that are trying to develop a monitoring system that combines multicompartmental modelling and atmospheric modelling. Tracing the advection of polluted air is another method that can be used by the governments. Trajectory statistics of air mass is clearly given in the guidance on the Global Monitoring Plan for constant organic pollutants of the Stockholm Convention as a tool to support the detection and interpretation of trends of POP concentrations in air (UNEP, 2007). Initially, trajectory statistical methods were used for the evaluation of source attribution related emission and distribution pattern of the traditional air pollutants (Stohl, 1998). In addition to this, residence time analysis was found to be helpful in assessing the influence of source area over the receptor sites through trajectory statistical methods (Zeng \& Hopke, 1989). Various researchers have tried to study the POPs using trajectory statistical methods (Eckhard et al., 2007; Hsu et al., 2003; Dvorská et al., 2008 and Kallenborn et al., 2007).

\section{Monitoring Human Exposure to POP}

Studies that have dealt with the amount of POPs in the human body have often come up against the same problem, which is that these pollutants tend to mix with other chemical agents in varying proportions. This makes it difficult to identify the concentrations of the POPs and their influences on the human body and also analyses of the population distribution of the concentrations of a given compound tend to reveal that individuals have a lower amount of POPs when compared to certain minority population (NRC (National Research Council), 2006; DHHS, 2009; Porta et al., 2008; Thornton et al., 2002; Health Canada, 2010; Patterson et al., 2009; Porta et al., 2010). Therefore, it is vital that the entire population distribution is analyzed for the concentrations of the numerous environmental chemicals as recommended by the committee from the National Research Council (NRC, 2006).

However, the concentration levels of individual compounds along with the number of compounds detected per person are routinely reported, with a greater emphasis on the former as the latter information may not be accurate primarily due to the fact that it does not account for the corresponding concentrations and is hence misleading (DHHS, 2009; Woodruff et al., 2011; Porta et al., 2010; Health Canada, 2010; Thornton et al., 2002 and Patterson et al., 2009). However, even a chemical by chemical analysis does not tackle the issue of multiple chemical concentrations along with the POPs (Kortenkamp et al., 2009; Gladen et al., 2003; Porta et al., 2008). The overall observation of the pollutants may be skewed because of the number of pollutants present with even a specific pollutant in sufficiently large quantities creating combination effects. Two crucial factors for combination effects to occur are the number of chemicals and their concentrations (Kortenkamp et al., 2009; NRC (National Research Council, 2008).

\section{Conclusion}

Today international and national environmental regulatory authorities who have a great deal of interest in protecting the environment and promoting sustainable activities are encouraged to ensure that they establish chronic as well as dedicated monitoring and research programs which are aimed at assessing the environment for the prevalence of POPs in different environments. The previous studies conducted are mostly long term in nature, there is a need for a research and monitoring strategy similar to those already established from other environments. There is an urgent need today for increased research opportunities and funding priorities in order to understand the growing impact of ecological risk related to POP contaminants to the environment as a result of comprehensive long term studies. Nowadays, most of the countries are encouraging the environmental scientists to focus more on this environmental pollution and to bridge the research gaps found in this field. Till date, there is no adequate research to draw a proper conclusion for solving and managing the impacts of persistent anthropogenic pollutants. As a result, the researcher of this study has driven the conclusion based on the conclusions from similar studies. 


\section{References}

Aboul-Kassim, T., \& Simueit, B. (1995). Environ. Sci. Technol., 29, 247. http://dx.doi.org/10.1021/es00010a004

Agency for Toxic Substance and Disease Registry (ATSDR). (1995). Toxicology Profile for Polycyclic Aromatic Hydrocarbons US Department of Health and Human Services. Atlanta, GA: Public Health Service.

Barrie et al. (1992). Arctic contaminants: sources, occurrence and pathways. The Science of the Total Environment, 122, 1-74. http://dx.doi.org/10.1016/0048-9697 (92)90245-N

Barrie, L. A. (1986). Arctic air pollution: an overview of current knowledge. Atmos. Environ., 20, 643-663. http://dx.doi.org/10.1016/0004-6981 (86)90180-0

Berg et al. (1998). Toxic equivalency factors (TEFs) for PCBs, PCDDs, PCDFs for humans and wildlife. Environ. Health Perspect, 106, 775. http://dx.doi.org/10.1289/ehp.98106775

Bidleman et al. (1989). Toxaphene and other organochlorines in Arctic Ocean fauna: evidence for atmospheric delivery. Arctic, 42, 307-313.

Bidleman, T. F., Walla, M. D., Roura, R., Carr, E., \& Schmidt, S. (1993). Organochlorine pesticides in the atmosphere of the Southern Ocean and Antarctica. Mar. Poll. Bull., 26, 258-262. http://dx.doi.org/10.1016/0025-326X (93)90064-Q

Bolt, H., \& Degen, G. (2002). Comparative assessment of endocrine modulators with oestrogenic activity. II. Persistent organochlorine pollutants. Arch. Environ. Contam. Toxicol., 76, 187.

Borges, J., Cabrera, J., Delgado, M., Suarez, E., \& Sauco, V. (2009). Analysis of pesticide residues in bananas harvested in the Canary Islands (Spain). Food Chem., 113, 313. http://dx.doi.org/10.1016/j.foodchem.2008.07.042

Bouwman, H. (2003). POPs in Southern Africa. In H. Fiedler (Ed.), The Hand Book of Environmental Chemistry, Persistent Organic Pollutants (3rd ed.). Springer- Verlag, Berlin/Heidelberg. http://dx.doi.org/10.1007/10751132_11

Bowes, G. W., \& Jonkel, C. J. (1975). Presence and distribution of polychlorinated biphenyls (PCB) in Arctic and subarctic marine food chains. J. Fish. Res. Board Can., 32, 2111-2123. http://dx.doi.org/10.1139/f75-249

Chen, Y., Wang, C., \& Wang, Z. (2005). Residues and source identification of persistence organic pollutants in farmland soils irrigated by effluents from biological treatment plans. Environ. Int., 31, 778. http://dx.doi.org/10.1016/j.envint.2005.05.024

Clausen, J., \& Berg, O. (1975). The content of polychlorinated hydrocarbons in Arctic ecosystems. Pure Appl. Chem., 42, 223-232. http://dx.doi.org/10.1351/pac197542010223

Covaci, A., \& Schepens, P. (2001). Chromatographic aspects of the analysis of selected persistent organochlorine pollutants in human hair. Chromatographia, 53, 366. http://dx.doi.org/10.1007/BF02490358

DeVoto, E., Kohlmeier, L., \& Heeschen, W. (1998). Some dietary predictors of plasma organochlorine concentrations in an elderly German population. Arch. Environ. Health, 53, 147-155. http://dx.doi.org/10.1080/00039896.1998.10545976

Dewailly, E., Nantel, A., Weber, J. P., \& Meyer, F. (1989). High levels of PCBs in breast milk of Inuit women from Arctic Quebec. Bull. Environ. Contam. Toxicol., 43, 641-646. http://dx.doi.org/10.1007/BF01701981

DHHS (Department of Health and Human Services). (2009). Fourth national report on human exposure to environmental chemicals. Atlanta: Centers for Disease Control and Prevention. Retrieved January 28, 2012, from http://www.cdc.gov/exposurereport/index.html

Dvorska, A., Lammel, G., Klanova, J., \& Holoubek, I. (2008). Kosetice, Czech Republic - ten years of air pollution monitoring and four years of evaluating the origin of persistent organic pollutants. Environmental Pollution, 156, 403-408. http://dx.doi.org/10.1016/j.envpol.2008.01.034

Eckhard, S., Breivik, K., Manø, S., \& Stohl, A. (2007). Record high peaks in PCB concentrations in the Arctic atmosphere due to long-range transport of biomass burning emissions. Atmospheric Chemistry and Physics, 7, 4527-4536. http://dx.doi.org/10.5194/acp-7-4527-2007

Ekmekci, M. (2005). Pesticide and nutrient contamination in the Kestel polje-Kirkgoz karst springs, Southern Turkey. Environ. Geol., 49, 19. http://dx.doi.org/10.1007/s00254-005-0022-2

El-Shahawi, M. S., Hamza, A., Bashammakh, A. S., \& Al-Saggaf, W. T. (2010). An overview on the accumulation, distribution, transformations, toxicity and analytical methods for the monitoring of persistent organic pollutants. Talanta, 80(5), 1587-1597. http://dx.doi.org/10.1016/j.talanta.2009.09.055

Fernandez, P., Carrera, G., \& Grimalt, J. O. (2005). Persistence organic pollutant in remote freshwater ecosystems. J. Grimalt. Aquat. Sci., 67, 263.

Fiedler, H. (2003). Dioxins and furans (PCDD/PCDF). In O. Hutzinger (Ed.), The Handbook of Environmental 
Chemistry, 3, 123-201. Berlin: Springer.

Galiulin, R., Bashkin, V., \& Galiulina, R. (2002). Water Air Soil Pollut., 137, 179. http://dx.doi.org/10.1023/A:1015558526154

George, J. L., \& Frear, D. E. H. (1966). Pesticides in the Antarctic. J. Appl. Ecol., 3, 155-167. http://dx.doi.org/10.2307/2401454

Gioia, R., Sweetman, A. J., \& Jones, K. C. (2007). Coupling passive air sampling with emission estimates and chemical fate modeling for persistent organic pollutants: a feasibility study for northern Europe. Environmental Science and Technology, 41, 2165-2171. http://dx.doi.org/10.1021/es0626739

Gladen, B. C., Doucet, J., \& Hansen, L. G. (2003). Assessing human polychlorinated biphenyl contamination for epidemiologic studies: lessons from patterns of congener concentrations in Canadians in 1992. Environ. Health Perspect, 111, 437-443. http://dx.doi.org/10.1289/ehp.5858

Goldberg, E. D. (1975). Synthetic organohalides in the sea. Proc. Royal Soc. Lond., 189, 277-289. http://dx.doi.org/10.1098/rspb.1975.0057

Gregor, D. J., \& Gummer, W. D. (1989). Evidence of atmospheric transport and deposition of organochlorine pesticides and polychlorinated biphenyls in Canadian Arctic snow. Environ. Sci. Technol., 23, 561-565. http://dx.doi.org/10.1021/es00063a008

Guitart, C., Flor, N., Dachs, J., Bayona, J., \& Albaiges, J. (2004). Evaluation of sampling devices for the determination of polycyclic aromatic hydrocarbons in surface microlayer coastal waters. Mar. Pollut. Bull., 48, 961. http://dx.doi.org/10.1016/j.marpolbul.2003.12.002

Guzella, L., Rscioli, C., Vigano, L., Sarkar, S., \& Bhaltacharya, A. (2005). Environ. Int., 31, 523. http://dx.doi.org/10.1016/j.envint.2004.10.014

Hargrave, B. T., Vass, W. P., Erickson, P. E., \& Fowler, B. R. (1988). Atmospheric transport of organochlorines to the Arctic Ocean. Tellus, 40B, 480-493. http://dx.doi.org/10.1111/j.1600-0889.1988.tb00118.x

Harrad, S. (Ed.) (2009). Persistent Organic Pollutants, 288. Hoboken, NJ: John Wiley \&sons. http://dx.doi.org/10.1002/9780470684122

Health Canada (2010). Report on human biomonitoring of environmental chemicals in Canada. Results of the Canadian Health Measures Survey Cycle 1 (2007-2009). Ottawa, Ontario: Health Canada.

Heim, S., Schwarzbauer, J., Kronimus, A., Littke, R., \& Herger, A. (2003). Organic pollutants in riparian wetlands of the Lippe River (Germany). Environ. Chem. Lett., 1, 169. http://dx.doi.org/10.1007/s10311-003-0040-9

Hela, D., Konstantinou, I., Sakellarides, T., Lambropoulou, D., Akriotis, T., \& Albanis, T. (2006). Persistent Organochlorine Contaminants in Liver and Fat of Birds of Prey from Greece. Arch. Environ. Contam. Toxicol., 50, 603. http://dx.doi.org/10.1007/s00244-005-0101-0

Hjelmborg, P., Ghisari, M., \& Jorgensen, E. (2006). SPE-HPLC purification of endocrine-disrupting compounds from human serum for assessment of xenoestrogenic activity. Anal. Bioanal. Chem., 385, 875. http://dx.doi.org/10.1007/s00216-006-0463-9

Hoff, R. M., Muir, D. C. G., \& Grift, N. P. (1992). Annual cycle of polychlorinated biphenyls and organohalogen pesticides in air in Southern Ontario. 2. Atmospheric transport and sources. Environ. Sci. Technol., 26, 276-283. http://dx.doi.org/10.1021/es00026a006

Hsu, Y. K., Holsen, T. M., \& Hopke, P. K. (2003). Comparison of hybrid receptor models to locate polychlorinated biphenyl sources in Chicago. Atmospheric Environment, 37, 545562. http://dx.doi.org/10.1016/S1352-2310(02)00886-5

Huang, X., Lessner, L., \& Carpenter, D. (2006). Exposure to persistence organic pollutants and hypersensitive disease. Environ. Res., 102, 101. http://dx.doi.org/10.1016/j.envres.2005.12.011

Iwata, H., Tanabe, S., Sakai, N., \& Tatsukawa, R. (1993). Distribution of persistent organochlorines in the oceanic air and surface seawater and the role of ocean on their global transport and fate. Environ. Sci. Technol., 27, 1080-1098. http://dx.doi.org/10.1021/es00043a007

Iwata, H., Tanabe, S., Sakai, N., Nishimura, A., \& Tatsukawa, R. (1994). Geographical distribution of persistent organochlorines in air, water and sediments from Asia and Oceania, and their implications for global redistribution from lower latitudes. Environ. Pollut., 85, 15-33. http://dx.doi.org/10.1016/0269-7491(94)90234-8

Juhasz, A., Smith, E., Smith, J., \& Naidu, R. (2003). Remediation of Persistent Organic Pollutants Using a Novel Two-Phase Soil Washing Biosorption Process. Water Air Soil Pollut.: Focus, 3, 233. http://dx.doi.org/10.1023/A:1023954406995

Kaiser, J. (2000). Endocrine disrupters. Panel cautiously confirms low-dose effects. Science, 290, 695-697. 
http://dx.doi.org/10.1126/science.290.5492.695

Kalantzi, O. I., Thomas, G. O., Alcock, R. E., Stephenson, A., \& Jones, K. C. (2001). The global distribution of PCBs and organochlorine pesticides in butter. Environ. Sci. Technol., 35, 1013-1018. http://dx.doi.org/10.1021/es0002464

Kallenborn, R. (2006). Persistent organic pollutants (POPs) as environmental risk factors in remote high-altitude ecosystems. Ecotoxicology and Environmental Safety, 63(1), 100-107. http://dx.doi.org/10.1016/j.ecoenv.2005.02.016

Kallenborn, R., Christensen, G., Evenset, A., Schlabach, M., \& Stohl, A. (2007). Atmospheric transport of persistent organic pollutants (POPs) to Bjørnøya (Bear Island). Journal of Environmental Monitoring, 9, 1082-1091.

Katsoyiannis, \& Samara, C. (2007). Comparison of active and passive sampling for the determination of persistent organic pollutants (POPs) in sewage treatment plants. Chemosphere, 67, 1375. http://dx.doi.org/10.1016/j.chemosphere.2006.10.035

Katsoyiannis, A., \& Samara, C. (2005). Persistent organic pollutants (POPs) in the conventional activated sludge treatment process: fate and mass balance. Environ. Res., 97, 245. http://dx.doi.org/10.1016/j.envres.2004.09.001

Kinloch, D., Kuhnlein, H., \& Muir, D. C. G. (1992). Inuit foods and diet: a preliminary assessment of benefits and risks. Sci. Tot. Environ., 122, 247-278. http://dx.doi.org/10.1016/0048-9697(92)90249-R

Kortenkamp, A., Backhaus, T., \& Faust, M. (2009). State of the art report on mixture toxicity. Final Report to the Environment Directorate General of the European Commission, Brussels. Retrieved December 22, 2009, from http://ec.europa.eu/environment/ chemicals/pdf/report_Mixture\%20toxicity.pdf

Korytar, D., Leonards, P., Bore, J., \& Brikmoan, U. (2002). High-resolution separation of polychlorinated biphenyls by comprehensive two-dimensional gas chromatography. J. Chromatogr., 958, 203. http://dx.doi.org/10.1016/S0021-9673(02)00327-8

Kumar, K., Watanable, K., Takemori, H., Iseki, N., Masunaga, S., \& Takasaga, T. (2005). Analysis of UNEP Priority POPs Using HRGC-HRMS and Their Contamination Profiles in Livers and Eggs of Great Cormorants (Phalacrocorax carbo) from Japan. Arch. Environ. Contam. Toxicol., 48, 538. http://dx.doi.org/10.1007/s00244-004-0030-3

Landaluze, J., Bartolome, L., Zuloaga, O., Gouzalez, L., Dietz, C., \& Camara, C. (2006). Accelerated extraction for determination of polycyclic aromatic hydrocarbons in marine biota. Anal. Bioanal. Chem., 384, 1331. http://dx.doi.org/10.1007/s00216-005-0249-5

Lee, D. H., Lee, I. K., Porta, M., Steffes, M., \& Jacobs, D. R. (2007). Relationship between serum concentrations of persistent organic pollutants and the prevalence of metabolic syndrome among nondiabetic adults: results from the National Health and Nutrition Examination Survey 1999-2002. Diabetologia, 50, 1841-1851. http://dx.doi.org/10.1007/s00125-007-0755-4

Lerche, D., van de Plassche, E., Swegler A., \& Balk, F. (2002). Selecting chemical substances foe the UN-ECE POP Protocol. Chemosphere, 47, 617-630. http://dx.doi.org/10.1016/S0045-6535(02)00028-0

Liem, A. K. D., F€urst, P., \& Rappe, C. (2000). Exposure of populations to dioxins and related compounds. Food Additives and Contaminants, 17, 241-259. http://dx.doi.org/10.1080/026520300283324

Loganathan, B., \& Kannan, K. (1994). Global organochlorine contamination trends: an overview. Ambio, 23, 187-191.

Lucaciu, C., Fayez, L., Reiner, E., Kolic, T., \& Boden, A. (2004). Advances in analytical techniques for polychlorinated dibenzo-p-dioxins, polychlorinated dibenzofurans and dioxin-like PCBs. Organohalog. Compd., 66, 153. Retrieved from http://www.10.1007/s00216-006-0479-1

Mannila, M., Koistinen, J., \& Vartianinen, T. (2002). Development of supercritical fluid extraction with a solid-phase trapping for fast estimation of toxic load of polychlorinated dibenzo-p-dioxins-dibenzofurans in sawmill soil. J. Chromatogr. A., 975, 189. http://dx.doi.org/10.1016/S0021-9673(02)01325-0

Matheus, D., Bononi, V., \& Machado, K. (2000). Biodegradation of hexachlorobenzene by basidiomycetes in soil contaminated with industrial residues. World J. Microbiol. Biotechnol., 16, 415. http://dx.doi.org/10.1023/A:1008910128114

Mes, J. (1987). PCBs in human populations. In J. S. Waid (Ed.), PCBs and the Environment, 3, 39-63. Boca Raton, FL: CRC Press.

Muir, D. C. G., \& Howard, P. H. (2006). Are there other persistent organic pollutants? A challenge for environmental chemists. Environmental Science and Technology, 40, 7157-7166. http://dx.doi.org/10.1021/es061677a 
Muir, D. C. G., Norstrom, R. J., \& Simon, M. (1988). Organochlorine contaminants in Arctic marine food chains: accumulation of specific polychlorinated biphenyls and chlordane-related compounds. Environ. Sci. Technol., 22, 1070-1078. http://dx.doi.org/10.1021/es00174a012

Myers, J. P. (2002). The latest hormone science part 4: Disrupting life's messages. Rachel's Environment and Health News, 753, 1-5.

Namiesnik, J., Zabigala, B., Kat-Wasik, A., Partyaka, M., \& Wasik, A. (2005). Passive sampling and/or extraction techniques in environmental analysis: a review. Anal. Bioanal., 381, 279. http://dx.doi.org/10.1007/s00216-004-2830-8

Norstrom, R. J., Simon, M., Muir, D. C. G., \& Schweinsberg, R. E. (1988). Organochlorine contaminants in Arctic marine food chains: identification, geographical distribution and temporal trends in polar bears. Environ. Sci. Technol., 22, 1063-1071. http://dx.doi.org/10.1021/es00174a011

NRC (National Research Council). (2006). Human Biomonitoring for Environmental Chemicals. Washington, DC: National Academies Press.

NRC (National Research Council). (2008). Committee on the Health Risks of Phthalates. Phthalates and cumulative risk assessment. Washington, DC: The National Academies Press. Retrieved January 28, 2012, from http://www.nap.edu/catalog/12528.html

OSPAR. (2004). OSPAR Commission Summary Record. OSPAR 04/23/1-E, Annex 17.

Ottar, B. (1981). The transfer of airborne pollutants to the Arctic regions. Atmos. Environ., 15, 1439-1445. http://dx.doi.org/10.1016/0004-6981(81)90350-4

Panic, O., \& Gorecki, T. (2006). Simultaneous determination of 405 pesticide residues in grain by accelerated solvent extraction then gas chromatography-mass spectrometry or liquid chromatography-tandem mass spectrometry. Anal. Bioanal. Chem., 384, 1366. http://dx.doi.org/10.1007/s00216-005-0237-9

Patterson et al. (2009). Levels in the U.S. population of those persistent organic pollutants (2003-2004) included in the Stockholm Convention or in other long range transboundary air pollution agreements. Environ. Sci. Technol., 43, 1211-1218. http://dx.doi.org/10.1021/es801966w

Pauwels, A., Covaci, A., Weyler, J., Delbek, L., \& Dhont, M. (2000). Comparison of persistent organic pollutant residues in serum and adipose tissue in a female population in Belgium, 1996-1998. Arch. Environ. Contam. Toxicol., 492, 65.

Petrlik, J., Zeme, D., \& Stiftung, H. (2001). Persistent Organic Pollutants in Poland. Waste Prevention Association " $3 R$ ”. Krakòw.

Poon, B., Leung, C., Wong, C., \& Wong, M. (2005). Polychlorinated Biphenyls and Organochlorine Pesticides in Human Adipose Tissue and Breast Milk Collected in Hong Kong. Arch. Environ. Contam. Toxicol., 49, 274. http://dx.doi.org/10.1007/s00244-004-0111-3

Porta et al. (2003). Persistent toxic substances and public health in Spain. Int. J. Occup. Environ. Health, 9, 112-117. http:// dx. doi. org/ 10.1136/jech.2004.021238

Porta et al. (2010). Distribution of blood concentrations of persistent organic pollutants in a representative sample of the population of Catalonia. Environ. Int., 36, 655-664. http://dx.doi.org/10.1016/j.envint.2010.04.013

Porta, M. (2002). Bovine spongiform encephalopathy, persistent organic pollutants and the achievable utopias. $J$. Epidemiol Community Health, 56, 806-807. http://dx.doi.org/10.1136/jech.56.11.806

Porta, M., \& Zumeta, E. (2002). Implementing the Stockholm treaty on POPs. Occup. Environ. Med., 59, 651-652. http://dx.doi.org/10.1136/oem.59.10.651

Porta, M., Puigdomènech, E., Ballester, F., Selva, J., Ribas-Fitó, N., Llop, S., \& López, T. (2008). Monitoring concentrations of persistent organic pollutants in the general population: The international experience. Environment International, 34(4), 546-561. http://dx.doi.org/10.1016/j.envint.2007.10.004

Rahn, K. A., \& Heidam, N. Z. (1981). Progress in Arctic air chemistry 1977-1980: a comparison of the first and second symposium. Atmos. Environ., 15, 1345-1348. http://dx.doi.org/10.1016/0004-6981(81)90339-5

Rappe, C. (1974). Chemical behavior of pesticides. In: Bylund, E., Linderholm, H. and Rune, O. (eds.). Ecological Problems of the Circumpolar Area, 29-32. Lulea, Sweden: Norrbottens Museum.

Rayne, S., Ikonomou, M., Butt, C., \& Diamond, M. (2005). Polychlorinated Dioxins and Furans from the World Trade Center Attacks in Exterior Window Films from Lower Manhattan in New York City. J. Troung. Environ. Sci. Technol., 39, 1995. http://dx.doi.org/10.1021/es049211k

Repetto, R., \& Baliga, S. S. (1996). Pesticides and the immune system: The public health risks. Washington, DC, USA: World Resources Institute. 
Risebrough, R. W., \& Carmignani, G. M. (1972). Chlorinated hydrocarbons in Antarctic birds. In B. C. Parker (Ed.), Proceedings of the colloquium. Conservation problems in Antarctica, 63-78. Lawrence, Kansas: Allen Press.

Ross, P. S., Couillard, C. M., Ikonomou, M. G., Johannessen, S. C., Lebeuf, M., Macdonald, R. W., \& Tomy, G. T. (2009). Large and growing environmental reservoirs of Deca-BDE present an emerging health risk for fish and marine mammals. Mar. Pollut. Bull., 58, 7-10. http://dx.doi.org/10.1016/j.marpolbul.2008.09.002

San, Y., Takaoka, M., Takeda, N., Matsumato, T., \& Osnita, K. (2005). J. Sep. Sci., $28,585$. http://dx.doi.org/10.1002/jssc.200401860

Sanpera et al. (2005). Persistent Organic Pollutants in Little Egret Eggs from Selected Wetlands in Pakistan. Arch. Environ. Contam. Toxicol., 44, 360. http://dx.doi.org/10.1007/s00244-002-2044-z

Sanz-Gallardo et al. (1999). Determinants of p,p-dichlorodiphenyldichloroethane (DDE) concentration in adipose tissue in women from five European cities. Arch. Environ. Health, 54, 277-283. http://dx.doi.org/10.1080/00039899909602486

Schafer, K. S., \& Kegley, S. E. (2002). Persistent toxic chemicals in the U.S. food supply. J. Epidemiol. Community Health, 56, 813-817. http://dx.doi.org/10.1136/jech.56.11.813

Schepens, P. J., Covaci, A., Jorens, P. G., Hens, L., Scharpé, S., \& Larebeke N. (2001). Surprising findings following a Belgian food contamination with PCBs and dioxins. Environ. Health Perspect, 109, 101-103. http://dx.doi.org/10.1289/ehp.01109101

Shatalov et al. (2005, July). Modelling of POP Contamination in the European Region: Evaluation of the Model Performance. EMEP Technical Report. Moscow: Meteorological Synthesizing Centre - East.

Simonich, S. L., \& Hites, R. A. (1995). Global distribution of persistent organochlorine compounds. Science, 269 , 1851-1854. http://dx.doi.org/10.1126/science. 7569923

Stohl, A. (1998). Computation, accuracy, and applications of trajectories - a review and bibliography. Atmospheric Environment, 32, 947-966. http://dx.doi.org/10.1016/S1352-2310(97)00457-3

Stokstad, E. (2004). Biomonitoring Pollution gets personal. Science, 304, 1892-1894. http://dx.doi.org/10.1126/science.304.5679.1892

Sweetman, M., Vall, K., Predouros, K., \& Tones. (2005). The role of soil organic carbon in the global cycling of persistent organic pollutants (POPs): Interpreting and modelling field data. Chemosphere, 60, 959. http://dx.doi.org/10.1016/j.chemosphere.2004.12.074

Tanabe, S., Tatsukawa, R., Kawano, M., \& Hidaka, H. (1982). Global distribution and atmospheric transport of chlorinated hydrocarbons HCH (BHC) isomers and DDT compounds in the Western Pacific, Eastern Indian and Antarctic Oceans. Journal of the Oceanographic Society of Japan, 38, 137-158. http://dx.doi.org/10.1007/BF02110285

Taylor, T., Waddell, D., Reiner, E., \& Macpherson, K. (1995). Direct Elution of Solid Phase Extraction Disks for the Determination of Polychlorinated Dibenzo-p-dioxins and Polychlorinated Dibenzofurans in Effluent Samples. Anal. Chem., 67, 1186. http://dx.doi.org/10.1021/ac00103a008

Thornton, J. W., McCally, M., \& Houlihan J. (2002). Biomonitoring of industrial pollutants: health and policy implications of the chemical body burden. Public Health Rep., 117, 315-323. http://dx.doi.org/10.1016/S0033-3549(04)50167-X

Uneo et al. (2003). Global pollution monitoring of PCBs and organochlorine pesticides using skipjack tuna as a bioindicator. Arch. Environ. Contam. Toxicol., 45, 378. http://dx.doi.org/10.1021/es070380p

UNEP (United Nations Environment Programme). (2007). Guidance on the Global Monitoring Plan for Persistent Organic Pollutants. Retrieved April 2, 2009, from http://www.pops.int/documents/meetings/cop_3/meetingdocs/inf14/GMP\%20Guidance\%20CD/Guidance.p df

UNIDO (United Nations Industrial Development Organization). (2000). Sectoral Profile of Brewing Industry. Retrieved from http://www.unido.org/ssites/env/sectors/sectors101.html

United Nations Environment Programme. (2007). Stockholm Convention on Persistent Organic Pollutants (POPs). Retrieved April 2, 2007, from http://www.pops.int

US Environmental Protection Agency. (1999). Method 1668, Revision A, Chlorinated Biphenyl Congeners in Water, Soil, Sediment and Tissue by HRGC/HRMS.

Vallack et al. (1998). Controlling persistent organic pollutants - what next? Environ. Toxicol. Pharmacol., 6, 143-175. http://dx.doi.org/10.1016/S1382-6689(98)00036-2

van Larebeke et al. (2001). The Belgian PCB and dioxin incident of January-June 1999: Exposure data and potential impact on health. Environ. Health Perspect, 109, 265-273. http://dx.doi.org/10.1289/ehp.01109265 
Vanbeuzekekom, A., Hijman, W., Berkhoff, C., Stoffessen, B., \& Denboer, A. (2003). Fast sample preparation involving MASE and coupled column normal phase liquid chromatography for the rapid trace analysis of dioxins in air-dust samples from fire catastrophe emissions. Talanta, 63, 1183. http://dx.doi.org/10.1016/j.talanta.2004.05.026

Villa, S., Finizio, A., Diazdiaz, R., \& Vighi, N. (2003). Distribution of Organochlorine Pesticides in Pine Needles of an Oceanic Island: The Case of Tenerife (Canary Islands, Spain). Water Air Soil Pollut., 146, 335. http://dx.doi.org/10.1023/A:1023906306701

Wang et al. (2010). Birthrates and delay times of Type Ia supernovae. Sci. China Ser. G., 53, 586. http://dx.doi.org/10.1007/s11433-010-0152-8

Wang, B., Huang, J., Deng, S. B., Yang, X. L., \& Yu, G. (2012). Addressing the environmental risk of persistent organic pollutants in China. Frontiers of Environmental Science and Engineering, 6, 2-16. http://dx.doi.org/10.1007/s11783-011-0370-y

Wang, J., Hung, C., Hsuang, C., \& Chien, G. (2009). Polychlorinated dibenzo-p-dioxin and dibenzofuran emissions from an industrial park clustered with metallurgical industries. J. Hazard. Mater, 161, 800. http://dx.doi.org/10.1016/j.jhazmat.2008.04.026

Wania, F., \& Mackay, D. (1993). Global fractionation and cold condensation of low volatility organochlorine compounds in Polar Regions. Ambio, 22, 10-18.

Wania, F., \& Mackay, D. (1996). Tracking the distribution of persistent organic pollutants. Environ. Sci. Technol., 30, 390-396. http://dx.doi.org/10.1021/es962399q

Weber, K., \& Goerke, H. (1996). Organochlorine compounds in fish off the Antarctic Peninsula. Chemosphere, 33, 377-392. http://dx.doi.org/10.1016/0045-6535(96)00204-4

Weinhold, B. (2003). Body of evidence. Environ. Health Perspect, 111, 394-399. http://dx.doi.org/10.1289/ehp.111-a394

Wenzl, T., Simon, R., Kleiner, J., \& Auklam, E. (2006). Trends Anal. Chem., 25, 716. http://dx.doi.org/10.1016/j.trac.2006.05.010

Weschler, C. J. (1981). Identification of selected organics in the arctic aerosol. Atmos. Environ., 15, 1365-1369. http://dx.doi.org/10.1016/0004-6981(81)90342-5

Woodruff, T. J., Zota, A. R., \& Schwartz, J. M. (2011). Environmental chemicals in pregnant women in the US: NHANES 2003-2004. Environ. Health Perspect, 119, 878-885. http://dx.doi.org/10.1289/ehp.1002727

Workshop on Contamination of Food and Agro Products. (2000). Presented at the ICS, UNIDO, Croatia.

Xie, S. G., Sun, W. M., Luo, C. L., \& Cupples, A. M. (2010). Stable isotope probing identifies novel m-xylene degraders in soil microcosms from contaminated and uncontaminated sites. Water Air Soil Pollut., 212, 113-122. http://dx.doi.org/10.1007/s11270-010-0326-z

Ying, Y., Yong, Y., Dawson, R., Yajuan, S., Zhang, H., Wong, T., Liu, W., \& Ren, H. (2005). A spatial temporal assessment of pollution from PCBs in China. Chemosphere, 60, 731. http://dx.doi.org/10.1016/j.chemosphere.2005.05.001

Zeng, Y., \& Hopke, P. K. (1989). A study of the sources of acid precipitation in Ontario. Atmospheric Environment, 23, 1499-1509. Canada. http://dx.doi.org/10.1016/0004-6981(89)90409-5

Zhao, G., Ying, Y., Han, G., \& Ling, B. (2006). Biotransfer of persistent organic pollutants from a large site in China used for the disassembly of electronic and electrical waste. Environ. Geochem. Health, 28, 341. http://dx.doi.org/10.1007/s10653-005-9003-3

Zhao, Y., Yang, L., \& Wang, Q. (2007). Pulsed large volume injection gas chromatography coupled with electron-capture negative ionization quadrupole mass spectrometry for simultaneous determination of typical halogenated persistent organic pollutants. J. Am. Soc. Mass Spectrom., 18, 1375. http://dx.doi.org/10.1016/j.jasms.2007.04.019

Zielinska, B., \& Samy, S. (2006). Anal. Bioanal. Chem., 384, 1383.

\section{Copyrights}

Copyright for this article is retained by the author(s), with first publication rights granted to the journal.

This is an open-access article distributed under the terms and conditions of the Creative Commons Attribution license (http://creativecommons.org/licenses/by/3.0/). 